\title{
Effect of Dreyfus Model of Training on Motor Vehicle Mechanic Work Students' Skill Acquisition in Technical Colleges in North East, Nigeria
}

\author{
George Nwachukwu Ogbonna, Abuubaida Abdullahi Shettima, \\ Victor Ikechukwu Oguejiofor, Samsun Ikenna Nwaodo, Kingsley Chimezia Udogu \\ Department of Industrial Technical Education, Faculty of Vocational Technical Education, University of Nigeria, Nsukka, Nigeria \\ Email address: \\ george.ogbonna@unn.edu.ng (G. N. Ogbonna), abuubaidaabdullahi@gmail.com(A. A. Shettima), \\ victor.oguejiofor@unn.edu.ng (V. I. Oguejiofor), samsun.nwaodo@unn.edu.ng (S. I. Nwaodo), kingsley.udogu@unn.edu.ng (K. C. Udogu)
}

\section{To cite this article:}

George Nwachukwu Ogbonna, Abuubaida Abdullahi Shettima, Victor Ikechukwu Oguejiofor, Samsun Ikenna Nwaodo, Kingsley Chimezia Udogu. Effect of Dreyfus Model of Training on Motor Vehicle Mechanic Work Students' Skill Acquisition in Technical Colleges in North East, Nigeria. International Journal of Mechanical Engineering and Applications. Vol. 9, No. 3, 2021, pp. 50-57. doi: 10.11648/j.ijmea.20210903.12

Received: April 18, 2021; Accepted: June 16, 2021; Published: August 19, 2021

\begin{abstract}
The study was a pre-test, post-test, non-equivalent control group quasi-experimental design. The study was to determine the effect of Dreyfus model of training on Motor Vehicle Mechanic Work students' skill acquisition in Technical Colleges. Specifically, the study seeks to find out the effect of using; Dreyfus model of training compared to Demonstration method on student's achievement on suspension system, braking system and student's interest on Motor Vehicle Mechanic Work Trade. The population for this study comprises of 233 respondents NTC II students of MVMW. The sample size for this study was 43 NTC students selected from the study. Instruments used for data collection were: Auto-mechanics Achievement Test (AAT) with 40 multiple questions, marking scheme answer options (A-D) and Auto-Mechanics Interest Inventory (AMII) with 30 items. Score guide sheet based on four-point rating scale used by teachers or ratter. The Cronbach Alpha Reliability Coefficient of the test instrument was used to determine the reliability coefficient of 0.81 , is obtained which were indicates that the instrument was reliable for the study. The data collected was analysed in line with the research questions and hypotheses. The interest inventory was analysed using mean and standard deviation. A mean of 3.50 and above will be considered interested, below that were considered not interested. the mean gain will be used to answer research questions one to four, while Analysis of covariance (ANCOVA) was used to test the null hypotheses at 0.05 level of significance with the use of Statistical Package for Social Sciences SPSS (Vision, 20). The effect was found to be significant, the study revealed that Dreyfus model is effective in enhancing students' skill acquisition in braking system, the effect was found to be significant, it was found out that Dreyfus model is effective in enhancing students' skill acquisition in suspension system, the effect was found to be significant. Therefore, the following recommendation are made: Motor vehicle mechanic work teachers should adopt Dreyfus model to improve teaching and learning of auto-mechanic courses, in preparing lesson plans/note, Motor vehicle mechanic work teachers should include Dreyfus model when teaching students in the class. Workshops, seminars and conference should be organized by Ministries of Education/NBTE to enlighten Motor vehicle mechanic work teachers on how to improve their knowledge and skills on the use of Dreyfus mode, and developers should carry out curriculum improvement to capture Dreyfus model for teaching activities and experiences.
\end{abstract}

Keywords: Technical Colleges, Motor Vehicle Mechanic Work (MVMW), Skill Acquisition, Dreyfus Model and Demonstration

\section{Introduction}

Technical Colleges are regarded as principal vocational institutions in Nigeria that give full training intended to prepare students for entry into various occupations. Technical Colleges are set up by Federal or State Government as 
principal vocational institutions intended to prepare individuals for entry into various occupations as craftsmen or Technician. The Federal Government of Nigeria FGN [17], stated that Technical Colleges are designed to prepare craftsmen and technicians at sub-professional levels. Technical College is a segment of Technical and Vocational Education (TVE) designed to produce craftsmen at the secondary school level and master craftsmen at the advanced craft level. According to Ndomi [26], Technical Colleges provide technical training in a number of courses which include General Education, Electrical/electronic trades, Building trades, Woodwork trades, Printing trades and Motor Vehicle Mechanic Work.

Motor Vehicle Mechanic Work (MVMW) is one of the trade subjects offered at the technical college level in Nigeria whose main objective is to equip students with the necessary basic knowledge, skills and attitude to be self-reliance. The goal of Motor Vehicle Mechanic work according to the National for Technical Education Board (NATEB) [24] is to produce skilled craftsmen with good knowledge of working principles of motor vehicles, the techniques and safety practices involved in its maintenance. According to Creswell, [11] an Automobile known as a Motor Vehicle Works is a complex technical system in which various sub-systems operate in harmony to discharge defined functions. Motor Vehicle Mechanic Work is designed to expose recipients to the activities of servicing and repair of Automobile (Omeji, [35]). According to the National for Technical Education Board (NATEB) [24] curriculum of Motor Vehicle Mechanic Work is designed to train and impart mechanic skills leading to the production of craftsmen, technicians and other skilled personnel that will be enterprising and self-reliant. Motor Vehicle Mechanic Work program in Technical Colleges is designed to produce competent craftsmen. In the view of Abubakar [2] the goal of Motor Vehicle Mechanic Work is to produce competent automobile mechanics with a sound practical and theoretical knowledge which should be able to diagnose, repair and/or maintain all types of diesel and petrol engines. Doyin [13] stated that Motor Vehicle Mechanic Work is one of the Technical College programs which involve the acquisition of scientific knowledge in maintenance and repairing of Motor Vehicles. Adam [3] stated that maintenance and repairing in automobile enable students of Motor Vehicle Mechanic Work to know different types of diesel and petrol automobile maintenance, when to maintain an Automobile, how to carry out maintenance and repairing on parts of the Automobile such as: brakes and suspension.

Braking system is the mechanism in motor vehicle which is used to slow down or stop the vehicle to rest within the shortest possible distance. Abduhamid and James [1], stated that braking system is used to stop the vehicle while ascending or descending along the slope. Ayman [5], stated that the function of braking system is to decelerate or decrease the speed of a vehicle. Braking system is used to stop a vehicle and hold it in stationary position with or without the presence of driver (Gobet and Chassy, [18]).
Therefore, braking and suspension systems work as dualpurpose system which contribute to the vehicle's handling and provide safety and comfort by keeping the vehicle's passengers comfortably isolated from bumps and vibrations.

The part which performs the isolation from the road shock inform of bounce, pitch and roll is called suspension system. Suspension system is the mechanisms that physically separate the vehicle body from the wheels of the vehicle. According to Vatankhah, [38] suspension consists of springs, shock absorbers and linkages that connect a vehicle to its wheels. Abubakar, [2] stated that the function of suspension system includes prevention of the vehicle body and frame from road shocks; safeguard the passengers and goods from road shock; give good road holding while driving and maximize the friction between the tires and the road as well as provide stability.

Skill acquisition is the systemic process of imbibing new ideas and knowledge of executing accurately professional function. According to Sagan [36] skill is the familiar knowledge of any art or science, united with readiness and dexterity in execution, performance, or application for practical purposes. Skill acquisition is a process and continuous development until the skills become natural to the individual through repetition or practice (Oke, [31]). Repetitive practical enables individual to acquire the knowhow of a variety of skills that is related to a particular trade. It is therefore important that the theories, models and practice of skill must be fully integrated into a pedagogical process of teachers for the purpose of effectiveness and worthwhile result. In a related development, Dekeyser [12] stated that skill acquisition involves the development of a new skill, practice or ways of doing things, usually gained through facilities training, experience or models.

Models can be used to facilitate learning especially where real objects may not serve the purpose. Macdonal [22] stated that model is a plan, design, and preliminary solid representation to be followed in construction, something to be copied. Nachimias and Nachimias [25] described model as a likeness of something and a representation of reality. In other words, model depicts the actual representation of the original. Model also explains how and why a particular phenomenon comes about. Ezeh [16] stated that a model is simplified structuring of reality which presents supposedly significant figures or relationships in a generalized form. The author further stated that all models have basic identities in terms of characters and functions, that model are dynamic. There are several types of models that have been developed by researchers for the purpose of acquiring skill in different field of knowledge such as Havensteins model, Regsdale's model, Gildford's model and Dreyfus model of skill acquisition.

Dreyfus model of skill acquisition is a model that explains how students acquire skills through formal instruction and practices. Benner [6] stated that Dreyfus model of skills acquisition is used fairly widely to provide a means of assessing and supporting progress in the development of skills and to provide a clear definition of acceptable levels for 
the assessment of practical skills experiences. According to Lester [21] practical experience with concrete cases can account for high levels of performance by Dreyfus five-stage model of skill acquisition. The basic premise of the Dreyfus model is that students' progress through five stages of expert status in this specific order: Novice, Advanced Beginner, Competent, Proficient, and Expert. Dreyfus and Dreyfus [14] noted that for an individual becomes expert, the individual depends less on abstract principles and more on concrete experience unlike the novice stage.

A novice stage is characterized by in-experience or inability of a learner to perform an action poorly due to inexperience, and/or lack of skill due to insufficient training. According to Ogbuanya and Fakorede [30], novice is characterized by recognition of relevant discrete facts, features, and rules for decision-making that are so clearly and objectively defined as to be virtually context-free in application. Lester [21] explained that novice stage applies to any age, but most often describes young or early learners. Similarly, Hargreaves and Lane [19] noted that novice thinks through the analytical process and decides the course of action to take to solve the problem. The authors further stated that novice in the process of automobile skills acquisition is expected to follow the master craftsman, by asking questions, observing actions but do not take action. Novice in any skills generally does not have responsibility for outcomes of an action like advanced beginner.

Advanced beginner is a step-in skill acquisition, with learner beginning to perceive similarity of concrete situations with prior examples of the same experience. Holmboe and Hawkins [20] stated that advanced beginner is the stage of being efficient and skilful in parts of the practice area, requiring occasional supportive cues. According to Eboh, [15] advanced beginner is the one who can demonstrate marginally acceptable performance. Therefore, to improve advanced beginners of automobile mechanic to next level, (competent stage) there is need to gain experience dealing with real situations, preferably in limited and controlled situations (with much of the 'real-world complexity' filtered out) competently.

Competence is the ability to perform work to standard, measurable knowledge, skills or abilities and behaviors critical to successful job performance. Man, Lau, and Chan [23] viewed competence as the capacity to perform a task skillfully and effectively. Competence is the ability to perform a task with desirable outcomes. (Olaitan [33]). It is the interplay of interpersonal and technical skills with critical thinking, and it integrates the cognitive, affective, and psychomotor domains. Ogbuanya and Shetima [29] stated that competence means to perform a task with little or no mistake when measured with standard. Olaitan [33] viewed competence as the knowledge, skills, attitude and ability which are required in order to perform successfully at special proficiency level in a program.

Proficiency is the stage of an individual skill to become analytical, starting to draw on emotional experiences from successes and failures to help determine which elements of the situation or problem are important to focus on. According to Chapelle [10], proficiency is a stage the individual continues to increase in risk taking in the world of work. Also, Boston [7] stated that the proficiency, in the world of skilful activity, sees what needs to be done then decides on how to do it. Hence, advance to the expert level. Also, as much as possible, they should practice without being hindered by policies or guidelines (Benner, [6]). The intuition of the expert starts with a vast pool of practical knowledge, and that can only be developed by experimenting freely.

An expert is a logical end process of learning skill that is developed in form of modes and stages of operation. Dreyfus and Dreyfus [14] expressed this stage as the final stage of skill acquisition and practical operation. An expert sees the solution without having to pass through an analytical process to arrive at the solution. According to Boyalzis, [8], an expert is totally immersed in understanding the situation, making decisions on how to proceed in any situation. Therefore, an automobile expert is fully engaged in fluid, efficient performance, responsive to context. Chambers [9] stated that expert is the one who can demonstrate marginally acceptable performance to the leaners.

Demonstration is an act or method of showing someone how something is used or done. According to Abubakar [2], demonstration is the method of teaching learners how to perform manipulative operations. Olatoye [34] stated that an effective demonstration follows three steps of the learning cycle: stimulus step (introducing the problem), assimilative step (demonstration and development of the understanding by the learner) and application step. Okeke [32] observed that in teaching manipulative skills by the demonstration method, the teacher is concerned that the learner understands the logical step-by-step procedures in doing the job and apply the related information. In addition, Adekoya and Olatoye [4] pointed out that planning the logical step-by-step points or activities is the key to a successful demonstration. A point must be carefully demonstrated and explained to the learners by the teachers this helps to determine what will be the quality of student's interest in a particular learning environment.

Student's interest has been described as the attraction, which forces or compels a learner to respond to a particular stimulus. Interest increases learning and promoting interest in the classroom increases students' intrinsic motivation to learn (Zadina [39]). Students' interest in any learning activity is sustained by the active involvement of the learner in all aspect of the learning process. Nworgu [27] sees interest as the cause of certain actions, acting as a drive or motivation that propels people to act in certain ways either externally or internally. In other words, learner's interest in an activity increases the strength of ego-involvement of the learner and does not allow the learner to be distracted by trivial extraneous events around him/her. Obodo [28], maintained that interest controls the motivation to learn, thus, it has a direct relationship with students' achievement in any Technical College subject.

A number of factors have been found to have contributed 
to student's poor achievement in the technical college. The National Business and Technical Examination Board (NABTEB) May/June Chief examiner's report [24], indicated that the shortcomings of the present teaching method partly accounted for the poor performance of students in Motor Vehicle Mechanic Work in the National Technical Certificate Examination in recent years. According to NABTEB [24], the performance of students is poor. The report showed that the level of achievement in automechanics subjects was lower than expectation as most students scored less than 50 percent in the subject. This low achievement may be due to the method of teaching adopted by auto-mechanics teachers in the Technical Colleges. Sofolahan [37], further maintained that when demonstration method of teaching is employed, students' ability to grasp relevant concepts is made much more difficult than when students are exposed to lessons. There is thus the need to investigate the effectiveness of other teaching methods to students in auto-mechanics trade in the Technical Colleges which would make learning more concrete. Ogbuanya and Shetima [29], stated that the skill the technical teacher acquired during training becomes obsolete as time goes on. Therefore, the critical need for automobile graduates to stand the global challenges of modern technology in automobile industries and it became necessary to explore the effect of Dreyfus model of training on Motor Vehicle Mechanic Work students' skill acquisition in Technical Colleges in North East Nigeria.

\subsection{Statement of the Problem}

The teachers of Motor Vehicle Mechanic Work in Technical College are to equip students with necessary theoretical knowledge and practical skills that will enable the graduates of Motor Vehicle Mechanic Work to set up their own workshops, self-employed and even employ others. Motor Vehicle Mechanic work exposes students to various skills in motor vehicle maintenance and repairing. Most of the new automobile vehicles are now built with automobile sophisticated breaking technologies and competitive industrial/electronic, changing's and development in suspension and braking system which these Motor Vehicle Mechanics Work graduates need to be familiar with before graduation.

Motor Vehicle Mechanic Work graduate's unemployment has reached alarming proportions as a result of low skills they acquired while in Colleges. Those students who eventually study Motor Vehicle Mechanic work in the Technical Colleges do not perform well in the National Business and Technical Examination Board (NABTEB) examination. The National Business and Technical Examination Board (NABTEB) May/June Chief examiners ${ }^{\text {ee }}$ report [24], indicated that the shortcomings of teaching method partly accounted for the poor performance of students in Motor Vehicle Mechanic Work in the National Technical Certificate Examination in recent years. According to NABTEB [24], the performance of students in National Technical Certificate (NTC) Examination was poor.
However, motor vehicle mechanic graduates find it difficult to maintain and repair modern automobile vehicles competently due to new electronics technology such as computer systems and microprocessors in form of electromechanical systems in automobile vehicles. These are due to techniques adopted in the process of skill acquisition. Therefore, it became necessary to determine the effect of using Dreyfus model of skill acquisition in suspension and braking systems in modern vehicle to enhancing technical skill acquisition of graduates of technical colleges in North East Nigeria.

\subsection{Purpose of the Study}

The major purpose of this study is to determine the effect of Dreyfus model of training on Motor Vehicle Mechanic Work students' skill acquisition in Technical Colleges. Specifically, the study seeks to find out the effect of using;

1. Dreyfus model of training compared to Demonstration method on student's achievement on suspension system.

2. Dreyfus model of training compared to Demonstration method on student's achievement on braking system.

3. Dreyfus model of training compared to Demonstration method on student's interest on Motor Vehicle Mechanic Work Trade.

\subsection{Hypotheses}

The following hypothesis was formulated to guide the study and was tested at 0.05 level of significance.

$\mathrm{H}_{01}$. There is no significant difference between the mean achievement scores of the students taught with Dreyfus model and those taught with Demonstration method on suspension system.

$\mathrm{H}_{02}$. There is no significant difference between the mean achievement scores of the students taught with Dreyfus model and those taught with the Demonstration method on braking system.

$\mathrm{H}_{03}$. There is no significant difference between the mean achievement scores of the students taught with Dreyfus model and student taught with the Demonstration method on students' interest on Motor Vehicle Mechanic Work Trade.

\section{Methodology}

The study was a pre-test, post-test, non-equivalent control group quasi-experimental design. The population for this study comprises of 233 respondents NTC II students of MVMW. The sample size for this study was 43 NTC students selected from the study. Instruments used for data collection were: Auto-mechanics Achievement Test (AAT) with 40 multiple questions, marking scheme answer options (A-D) and Auto-Mechanics Interest Inventory (AMII) with 30 items. Score guide sheet based on four-point rating scale used by teachers or ratters. The instruments were face and content validated by three experts. Two lecturers from the Department of industrial technical Education, University of Nigeria, Nsukka, one from Department of industrial technical 
Education, Federal University of Technology Minna. The Cronbach Alpha Reliability Coefficient of the test instrument was used to determine the reliability coefficient of 0.81 , is obtained which will indicates that the instrument was reliable for the study. The data collected was analysed in line with the research questions and hypotheses. The interest inventory will be analysed using mean and standard deviation. A mean of 3.50 and above will be considered interested, below that will be considered not interested. the mean gain will be used to answer research questions one and two, while Analysis of covariance (ANCOVA) will be used to test the null hypotheses at 0.05 level of significance with the use of Statistical Package for Social Sciences SPSS (Vision, 20).

\section{Presentation of Data and Analysis}

\section{Research Question 1}

What is the effect of Dreyfus model of training and Demonstration method on student's achievement on suspension system?

Table 1. Mean and standard deviation of pre-test and post-test scores of the experimental and control groups in suspension system.

\begin{tabular}{llllll}
\hline Treatment group & N & Pre-test mean & SD $_{1}$ & Post-test mean $_{\text {SD }}$ & Mean Gain \\
\hline Dreyfus model & 23 & 21.34 & 4.52 & 78.95 & 8.41 \\
Demonstration method & 20 & 19.05 & 5.38 & 65.45 & 4.01 \\
\hline
\end{tabular}

The data present in Table 1 shows that students taught with Dreyfus model had a Mean score of 21.34 and Standard Deviation of 4.52 in the pre-test and Mean score of 78.95 and Standard Deviation of 8.41 in the post-test making a pre-test and post-test Mean gain of 57.60 respectively. The students taught with Demonstration method had a Mean score of 19.05 and Standard Deviation of 5.38 in the pre-test and mean score of 65.45 and Standard Deviation of 4.01 in the post-test making a pre-test and post-test Mean gain of 46.40 respectively. With these results, both Dreyfus model and Demonstration method are effective in improving student's achievement test in chassis system but the effect of Dreyfus model in improving student's achievement test in suspension system is higher than the Demonstration method.

Research Question 2

What is the effect of using Dreyfus model of training and Demonstration method on student's achievement on braking system?

Table 2. Mean and standard deviation of pre-test and post-test scores of the experimental and control groups in braking system.

\begin{tabular}{llllll}
\hline Treatment group & N & Pre-test mean & SD $_{1}$ & Post-test mean & SD $_{\mathbf{2}}$ \\
\hline Dreyfus model & 23 & 22.6 & 4.27 & 76.3 & 9.05 \\
Demonstration method & 20 & 21.75 & 6.38 & 63.35 & 3.78 \\
\hline
\end{tabular}

The data present in Table 2 shows that students taught with Dreyfus model had a Mean score of 22.60 and Standard Deviation 4.27 in the pre-test and Mean score of 76.30 and Standard Deviation of 9.05 in the post-test making a pre-test and post-test Mean gain of 53.69 respectively. The students taught with Demonstration method had a pre-test Mean score of 21.75 and Standard Deviation of 6.38 in the pre-test and mean score of 63.35 and Standard Deviation of 3.78 in the post-test making a pre-test and post-test Mean gain of 41.60 respectively. With these results, both Dreyfus model and Demonstration method are effective in improving student's achievement test in braking system but the effect of Dreyfus model in improving student's achievement test in braking system is higher than the Demonstration method.

Research Question 3

What is the student's interest in Dreyfus model and Demonstration method of teaching Motor Vehicle Mechanic Work Trade?

Table 3. Mean and Standard Deviation of Pre-test and Post-test scores of the Experimental and Control Groups in Student's Interest in Motor Vehicle Mechanic Work.

\begin{tabular}{llllll}
\hline Treatment group & N & Pre-test mean & SD $_{\mathbf{1}}$ & Post-test mean $_{\text {SD }}$ & Mean Gain $_{\mathbf{2}}$ \\
\hline Dreyfus model & 23 & 22.44 & 2.1 & 79.94 & 5.32 \\
Demonstration method & 20 & 21.35 & 3.15 & 64.2 & 1.59 \\
\hline
\end{tabular}

The data present in Table 3 shows that students taught with Dreyfus model had a Mean score of 22.44 and Standard Deviation 2.10 in the pre-test and Mean score of 79.94 and Standard Deviation of 4.32 in the post-test making a pre-test and post-test Mean gain of 57.50 respectively. The students taught with Demonstration method had a Mean score of 21.35 and Standard Deviation of 3.15 in the pre-test and mean score of 64.20 and Standard Deviation of 1.59 in the post-test making a pretest and post-test Mean gain of 43.84 respectively. With these results, both Demonstration method and Dreyfus model are effective in enhancing students' skill acquisition in student's interest on Motor Vehicle Mechanic Work Trade, but the effect of Dreyfus model in improving students' achievement in student's interest on Motor Vehicle Mechanic Work Trade is higher than Demonstration method.

$\mathrm{H}_{01}$. There is no significant difference between the mean achievement scores of the students taught with Dreyfus model and those taught with Demonstration method on suspension system.

Data for testing the hypotheses are presented in Table 4. 
Table 4. Summary of Analysis of Covariance ANCOVA for testing Significance differences of the Effects of Dreyfus model and Demonstration method with respect to their Mean Scores on Suspension system on Students' Achievement Test.

\begin{tabular}{llllll}
\hline Source & Type III Sum of Squares & Df & Mean Square & F & Sig. \\
\hline Corrected Model & $1985.281^{\mathrm{a}}$ & 2 & 992.64 & 0 \\
Intercept & 10898.927 & 1 & 10898.927 & 21.695 \\
Suspensionsystem & 33.745 & 1 & 33.745 & 0.738 \\
Group & 1733.866 & 1 & 1733.866 & 37.895 \\
Error & 1830.161 & 40 & 45.754 & 0.396 \\
Total & 230923 & 43 & & 0 \\
Corrected Total & 3815.442 & 42 & & \\
\hline
\end{tabular}

*Significantat sig of $\mathrm{F}<0.05$.

The data presented in Table 4 shows F-calculated values of Effects of the Dreyfus model and Demonstration method on students' achievement test in suspension system. The Fcalculated value is 37.895 with a significance value of $F$ at 0.000 which is less than 0.05 . This means that there was significant mean difference between the Dreyfus model and Demonstration method on students' achievement test in suspension system. The null hypothesis for the effect of
Dreyfus model and Demonstration method on students' achievement is therefore rejected at 0.05 level of significance, while the alternative hypothesis is upheld.

$\mathrm{H}_{02}$. There is no significant difference between the mean achievement scores of the students taught with Dreyfus model and those taught with the Demonstration method on braking system.

Data for testing the hypotheses are presented in Table 5.

Table 5. Summary of Analysis of Covariance ANCOVA for testing Significance differences of the Effects of Dreyfus model and Demonstration method with respect to their Mean Scores on Braking system on Students' Achievement Test.

\begin{tabular}{llllll}
\hline Source & Type III Sum of Squares & df & Mean Square & F & Sig. \\
\hline Corrected Model & $1795.829^{\mathrm{a}}$ & 2 & 897.914 & 17.294 & 0 \\
Intercept & 11209.067 & 1 & 11209.067 & 215.889 & 0 \\
Braking system & 0.597 & 1 & 0.597 & 0.011 & 0.915 \\
Group & 1788.611 & 1 & 1788.611 & 34.449 & 0 \\
Error & 2076.823 & 40 & 51.921 & & \\
Total & 216256 & 43 & & & \\
Corrected Total & 3872.651 & 42 & & & \\
\hline
\end{tabular}

*Significantat sig of $\mathrm{F}<0.05$.

The data presented in Table 5 shows F-calculated values of Effects of the Dreyfus model and Demonstration method on students' achievement test in braking system. The Fcalculated value is 34.449 with a significance value of $\mathrm{F}$ at 0.000 which is less than 0.05 . This means that there was significant mean difference between the Dreyfus model and Demonstration method on students' achievement test in braking system. The null hypothesis for the effect of Dreyfus model and Demonstration method on students' achievement is therefore rejected at 0.05 level of significance, while the alternative hypothesis is upheld.

$\mathrm{H}_{03}$. There is no significant difference between the mean achievement scores of the students taught with Dreyfus model and students taught with the Demonstration method on student's interests on motor vehicle mechanic work.

Data for testing the hypotheses are presented in Table 6.

Table 6. Summary of Analysis of Covariance ANCOVA for testing Significance differences of the Effects of Dreyfus model and Demonstration method with respect to their Mean Scores on Students' interests on Motor Vehicle Mechanic Work.

\begin{tabular}{llllll}
\hline Source & Type III Sum of Squares & df & Mean Square & F & Sig. \\
\hline Corrected Model & $2684.629^{\mathrm{a}}$ & 2 & 789.079 & 28.345 & 0 \\
Intercept & 22306.076 & 1 & 22306.076 & 326.998 & 0 \\
Interests & 0.795 & 1 & 0.795 & 0.042 & 0.823 \\
Group & 2878.621 & 1 & 2878.621 & 44.332 & 0 \\
Error & 3006.533 & 40 & 62.291 & \\
Total & 406226 & 43 & & & \\
Corrected Total & 4873.561 & 42 & & & \\
\hline
\end{tabular}

*Significantat sig of $\mathrm{F}<0.05$.

The data presented in Table 6 shows F-calculated values of Effects of the Dreyfus model and Demonstration method on students' achievement test on interest's inventory in motor vehicle mechanic work. The F-calculated value is
44.332 with a significance value of $F$ at 0.000 which is less than 0.05. With this result, there is a significant mean difference between the achievement scores of students on Dreyfus model and Demonstration method on student's 
interests on motor vehicle mechanic work. The null hypothesis for the effect of Dreyfus model and Demonstration method on students' achievement test is therefore rejected at 0.05 level of significance, while the alternative hypothesis is upheld.

\section{Conclusion}

Based on the results of this study, which shows that Dreyfus model is more effective in improving students' interest in Motor Vehicle Mechanic Work, there was an effect attributable to students' interest in Motor Vehicle Mechanic Work. Dreyfus model is employed to teach Motor Vehicle Mechanic Work in Technical Colleges. These results, therefore, show that Dreyfus model is a viable teaching method for teaching/learning Motor Vehicle Mechanic Work in Technical Colleges.

Instruction based on Dreyfus model is a contemporary teaching approach which maximizes students' learning potentials by minimizing the problems caused by the students' individual differences and creating a learning environment appropriate for each student's intelligences. The Dreyfus model will give teachers the opportunity to engage the students in the learning process, which will increase their self-esteem and enthusiasm and their willingness to take ownership and responsibility for their learning. Thus, if Dreyfus model is adopted to teach service station in Technical Colleges, the Motor Vehicle Mechanic Work craftsmen will, undoubtedly, be equipped with knowledge and skills that will help them to easily adapt and apply their skills in Motor Vehicle Mechanic Work as well as perform and cope more effectively with complexities in the vast changing automobile world of work.

\section{Recommendations}

Based on the findings of the study, the following recommendations are made:

1) Workshops, seminars and conferences should be organized by State Science and Technical Schools Board to enlighten and train Motor Vehicle Mechanic Work teachers on the of Dreyfus model for improving students' skills acquisition, achievement and interest in studying Motor Vehicle Mechanic Work.

2) National Board for Technical Education (NBTE) should consider the review of curriculum for Motor Vehicle Mechanic Work with a view to incorporating activities that reflect Dreyfus model to enable students learns more effectively.

3) Motor Vehicle Mechanic Work teachers in Technical Colleges should adopt Dreyfus model in their classroom teaching. This will help the teachers equip Motor Vehicle Mechanic Work craftsmen with the knowledge and skills needed to easily cope and perform more effectively in the automobile world of work.

\section{References}

[1] Abduhamid, B. O. \& James, D. R. (2010). Relative effects of problem-solving and discussion methods on secondary school students ${ }^{\text {ee }}$ achievement in social studies. Unpublished Ph.D Thesis, Department of Curriculum and Teaching, University of Ado-Ekiti, Ado-Ekiti.

[2] Abubakar, S. M. (2013). Evaluation of vocational technical training programs in northern Nigeria prisons. Journal of league of researchers in Nigeria (JOLORN). 8 (1), 146-153.

[3] Adam, D. (2011). Challenges facing technical institute graduates in practical skills acquisition in the upper east region of Ghana. (Asia-Pacific Journal of Cooperative Education, 2011, 12 (2), 67-77.

[4] Adekoya, Y. M. \& Olatoye, R. A. (2011) "Effect of demonstration, peer-tutoring, and lecture teaching strategies on senior secondary school students"e achievement in an aspect of agricultural science". Pacific journal of science and technology. 12 (1): 320-332.

[5] Ayman, D (2009). Introduction to research in education. New York: Holt Rinehart and Winston.

[6] Benner, E. E. (1984). Towards taxonomy of educational objectives in the psycho productive domain. Nigerian Journal of Technical Education. NBTE: 2 (1), 23 -34.

[7] Boston, W. E. (2011). Hand book for development competency-based training programmes Englewood cliffs N. J. prentice Hall. G85.

[8] Boyalzis, N. A. (2013). A goodwill message presented at the national workshop on revamping technical education in Nigeria organized for teachers of technical colleges and C. O. E. (Tech) by ETF at chelsea hotel Abuja. June 22nd$23 r d$.

[9] Chambers, D. W. (2012). Dental education's involvement with dentists' learning in practice: Data and theory. Journal of Dental Education, 76, 107-117.

[10] Chapelle, C. A. (2009). The relationship between second language acquisition theory and computer-assisted language learning. The Modern Language Journal, 93, 741-753. doi: 10.1111/j.1540-4781.2009. 00970.x.

[11] Creswell, J. (2003). Research design, qualitative, quantitative, and mixed methods approach, 2nd edition. Thousand Oaks: Sage Publications.

[12] Dekeyser, R. (2007). Theories in second language acquisition: An introduction (pp. 97-113). New Jersey: Lawrence Erlbaum Associates, Inc.

[13] Doyin, O. O. (2004). Strategies for improving the teaching and learning of motor vehicle mechanic trade in some selected technical colleges in Osun State. Unpublished B. Ed (Tech) Project. Kaduna Polytechnic, Kaduna.

[14] Dreyfus S, \& Dreyfus H. (1986). A five-stage model of the mental activities involved in directed skill acquisition. California University Berkeley Operations Research Center [monograph on the Internet]; Available from: http://www.dtic.mil/dtic/index.html [downloaded 12 January 2009]. 
[15] Eboh, E. C, (2009). Developing conceptual framework for empirical research: developing research skill, concept and conceptual framework. Edited by Anyokoha, E. U. Publication of Home Economic Research Association of Nigeria.

[16] Ezeh, E. O. (2006). The students under achievement in science, who is to blame? In Bello, O. O. (ed). 27th STAN Annual Conference Proceedings. 105-116.

[17] Federal Republic of Nigeria. (2004). National policy on education 4th ed. Nigerian educational research and development council (NERDC) press, Lagos, Lagos State, Nigeria.

[18] Gobet, R. O \& Chassy, L. D (2008) An Initial Investigation of the applicability of the Dreyfus skill acquisition model to the professional development of nurse educators. Theses, dissertations and capstones. Paper 371.

[19] Hargreaves J, \&Lane D. (2001). Delya's story: from expert to novice, a critique of Benner's concept of context in the development of expert nursing practice. Int J Nurs Stud.; 38: 389-94.

[20] Holmboe E. S, \& Hawkins R. E. (2008). Practical guide to the evaluation of clinical competence. Philadelphia, PA: Mosby Elsevier; pp. 5-6.

[21] Lester, P. O. (2005). An In-depth review and assessment of the present state and focus of technical and vocational education in Nigeria. A paper presented at National Seminar on TVE in Nigeria; vision and action 31st october - 2nd november. National Center for Women Development, Abuja.

[22] Macdonal, A. M. (2009). Chambers' twentieth century dictionary: London: the pitman press.

[23] Man, V. B, lau, A \& Chan, B. (2002). Key terms in second language acquisition. New York: Continuum International Publishing Group.

[24] NABTEB. (2002). May/june 2002 national technical certificate (NTC) and national business certificate (NBC) examinations: Chief examiner's report. National Business and Technical Examinations Board (NABTEB), fiesta printing press Ltd., Benin City, Edo state, Nigeria.

[25] Nachimias, C. F. \& Nachimias, D. (2002). Research Methods in Social Sciences. London: Edward Arnold Ltd.

[26] Ndomi, B. M. (2005). Revisiting the learning experience of technical college farm machinery curriculum for empowerment of recipients in Nigeria. Journal of Nigerian Association of Teachers of Technology (JONATT). 5 (1) 88 - 94.

[27] Nworgu, J. A. (2004). Relative effects of programmed instruction and demonstration methods on students' academic performance in science. College Students Journal. 2 (4): 46-57.

[28] Obodo, S. T. (2004). Survey of vocational education facilities in government technical colleges in Rivers State. Journal of Nigerian Association of Teachers of Technology (JONATT). 4 (1), $175-181$
[29] Ogbuanya, T. C \& Shetima, A. (2014). Strategies for enhancing entrepreneurship development for school to work transition of electrical installation graduates of tertiary institutions in Northern. Nigeria Journal of Faculty of Education University of Nigeria Nsukka.

[30] Ogbuanya, T. C. \& Fakorede, S. O. A. (2013). Effect of learning mode on the psychomotor achievement of automobile technology students in the technical colleges. In B. G. Nworgu (Eds). Education in the information age: Global challenges and enhancements strategies, 149 - 155; Nsukka; University Trust Publishers.

[31] Oke, M. (2005). Instructed acquisition of speaking: Reconciling theory and practice. In M. Pawlak, E. WaniekKlimczak, \& J. Majer (Eds.), Speaking and instructed foreign language acquisition (pp. 3-23). New York: Multilingual Matters.

[32] Okeke, C. C. (2011), Provision for the pre - vocational subjects at the JSS level in Anambra State. Problem and strategies. In E. T. Ehiametalor, (Ed). Implemtation of the National Policy on education, Benin City: NERA Publications.

[33] Olaitan, S. O. (2007). Vocational and technical education in Nigeria. Onitsh Noble Publishers.

[34] Olatoye, R. A. (2008). Self-concept and science achievement in co-educational and single-sex junior secondary school in Ogun State, Nigeria. Review of Higher Education and SelfLearning. 1 (1): 69-74. http://www.intellectbase.org.

[35] Omeji, D. A. (2005). Quantity, quality, production and distribution of teaching resources/facilities. In O. Nnoli \& I. Sulaiman (Eds). Reassessing the future of education in Nigeria. Abuja: ETF publication.

[36] Sagan, B. A. (2006). Development and managing schools workshop towards achieving Sustainable NEEDS. In G. N. Nneji, M. A. Ogunyemi, F. O. N. Onyeukwu, M. Ukponson, S. O. Agbato, E. A. Nnenji (Eds.), Technology Education as an impetus for sustainable NEEDS. 17th Annual NATT Conference-Abuja. $94-97$.

[37] Sofolahan, J. A. O. (2006). Primary school curriculum modules- primary six. prepared by national primary education commission. Abuja: National Implementation Committee on National Policy on Education.

[38] Vatankhak, V. O. (2009). Technical education and its challenges in Nigeria in the 21 st century. International $N G O$ $\begin{array}{llllll}\text { journal, } & 5 & \text { (2), } & 040 & - & 044 .\end{array}$ http://www.academicjournals.org/ingoj Retrieved on $15 / 02 / 2012$

[39] Zadina, I. Y. (2014). Mechanism for improving the funding of vocational centers and technical colleges in a democracy. Journal of Nigerian Association of Teachers of Technology (JONATT). 5 (1) 113 - 118. Repositioning workshops for efficiency. 